\title{
THE CONSTITUENCY COMMISSION
}

\author{
Adrian Kavanagh \\ Department of Geography/National Institute for Regional and Spatial Analysis \\ NUI Maynooth
}

The lead up to the next general election began on 7 January 2004, with the publication of the Constituency Commission report on recommended Dáil constituency boundaries for that election. Differential levels of population change between 1996 and 2002, with particularly high levels of population increase in eastern Ireland, ensured that considerable changes to boundaries would be involved. Seat losses were expected in Cork, the North West and North Midlands area, and the North City constituencies in Dublin. Seat gains were expected for the commuter-belt counties of Kildare and Meath, as well as for the rapidly growing western suburbs of Dublin. The decisions of the commission were of great interest to the different political parties, as well as to individual politicians for whom a boundary change might greatly impact on their future electoral prospects. The report was also likely to have a particular bearing on certain areas and their representation levels, as well as their levels of political engagement and participation.

The Constituency Commission was established on 9 July 2003, after the publication of the first volume of Census 2002. The remit of the commission was to make reports relating to the drawing up of constituency boundaries for elections to the European Parliament and Dáil Éireann. In relation to Dáil constituency boundaries, the terms of reference for the commission were set out in Section 6 of the 1997 Electoral Act. This stated that the total number of members of the Dáil was to be set between 164 and 168. Constituencies were to be represented by either three, four or five TDs, with these constituencies to be composed of contiguous areas. The boundaries drawn up were to avoid the breaching of county boundaries, as far as could be possible, with due regard also to be taken of significant physical features and the population density in constituencies, as well as to ensure continuity with the previous boundary configuration. The ratio between the number of TDs and the population 
in a constituency were also to be similar for each constituency, as far as could be practicable (Constituency Commission, 2004).

The latter provision determined the basis under which the commission was required to make changes to the existing electoral boundaries. The context in which the commission was working was one in which considerable demographic change had taken in the Republic of Ireland over the previous intercensal period. The national population had reached 3,917,203 in 2002, an increase of 291,116, or 8.0 per cent, on the 1996 figures. There were significant geographical variations across the country in terms of this population change, with high levels of increase in the eastern part of the country, particularly within the rapidly expanding commuter belt of Dublin. Population increased by 22.1 per cent in Meath, 21.4 per cent in Kildare and 17.1 per cent in Fingal, with the extension of the commuter belt being further evidenced in the population increases in Midland counties, such as Westmeath (13.5 per cent) and Laois (11.0 per cent). Other parts of the country experienced significantly lower levels of population increase, such as Longford (3.0 per cent), Leitrim ( 3.0 per cent) and Roscommon (3.5 per cent), while the population of Cork City fell by 3.2 per cent. Within Dublin, the population increased by very high levels in the inner city and western suburbs, while large tracts of the inner suburbs experienced population decline. The population of the Dublin Inner City increased by 23.4 per cent between 1996 and 2002, with these increases largely resulting from a mushrooming of private apartment development and the concentrating of immigrant populations in this area. In the western suburbs, the population in Lucan South increased by 13,356 (179.3 per cent), with similarly high levels of increase in Blanchardstown-Abbotstown (65.7 per cent) and Blanchardstown-Blakestown (61.3 per cent). These differential levels of population change required the commission to give extra seats to areas such as Kildare, Meath and the western suburbs of Dublin and to take seats from Cork, the North West and North Midlands areas, and the North City inner suburbs of Dublin. Considerable variances from the national mean were associated with constituencies in these areas, as is illustrated by Table 1. A number of constituencies had population per TD ratios that were well in excess of the national average, including Kildare North, Dublin West, Dublin Mid West and Meath, whereas the ratios in constituencies such as Dublin North West and Sligo Leitrim were well below the average. The extent of these variations meant that the changes in the commission's report would need to be far more widespread than in the previous 1998 report, which had been largely concerned with amending the configuration of Dáil constituency boundaries within the Dublin region. 
TABLE 1

RECOMMENDED CHANGES TO DÁIL CONSTITUENCY BOUNDARIES AND SUBSEQUENT CHANGES TO POPULATION TO TD RATIOS

\begin{tabular}{|c|c|c|c|c|c|}
\hline \multicolumn{3}{|c|}{ Before boundary changes } & \multicolumn{3}{|c|}{ After boundary changes } \\
\hline Constituency (2002) & $\begin{array}{c}\text { Population per } \\
\text { TD }( \pm \text { national } \\
\text { mean in } \%)\end{array}$ & $\begin{array}{l}\text { Seats } \\
(2002)\end{array}$ & $\begin{array}{l}\text { Gain or loss } \\
\text { of seat }\end{array}$ & $\begin{array}{c}\text { Population per } \\
\text { TD }( \pm \text { national } \\
\text { mean in } \%)\end{array}$ & $\begin{array}{c}\text { Territorial } \\
\text { changes }\end{array}$ \\
\hline Carlow-Kilkenny & $24,544(+4.0 \%)$ & 5 & No & $24,544(+4.0 \%)$ & No \\
\hline Cavan-Monaghan & $21,828(-7.5 \%)$ & 5 & No & $21,828(-7.5 \%)$ & No \\
\hline Clare & $24,841(+5.3 \%)$ & 4 & No & $24,585(+4.2 \%)$ & Yes - Minor \\
\hline Cork East & $22,711(-3.8 \%)$ & 4 & No & $22,711(-3.8 \%)$ & No \\
\hline Cork North Central & $21,713(-8.0 \%)$ & 5 & Yes; $4(-1)$ & $22,412(-5.0 \%)$ & Yes - Major \\
\hline Cork North West & $21,430(-9.2 \%)$ & 3 & No & $24,136(+2.3 \%)$ & Yes - Major \\
\hline Cork South Central & $23,356(-1.0 \%)$ & 5 & No & $24,765(+4.9 \%)$ & Yes - Major \\
\hline Cork South West & $22,449(-4.9 \%)$ & 3 & No & $23,701(+0.4 \%)$ & Yes - Major \\
\hline Donegal North East & $24,654(+4.5 \%)$ & 3 & No & $22,858(-3.1 \%)$ & Yes - Major \\
\hline Donegal South West & $21,205(-10.1 \%)$ & 3 & No & $23,000(-2.5 \%)$ & Yes - Major \\
\hline Dublin Central & $25,002(+6.0 \%)$ & 4 & No & $24,764(+4.9 \%)$ & Yes - Minor \\
\hline Dublin Mid West & $27,245(+15.5 \%)$ & 3 & Yes; $4(+1)$ & $23,448(-0.6 \%)$ & Yes - Major \\
\hline Dublin North & $25,698(+8.9 \%)$ & 4 & No & $24,716(+4.8 \%)$ & Yes - Minor \\
\hline Dublin North Central & $21,085(-10.7 \%)$ & 4 & Yes; $3(-1)$ & $24,500(+3.8 \%)$ & Yes - Major \\
\hline Dublin North East & $22,351(-5.3 \%)$ & 3 & No & $24,291(+2.9 \%)$ & Yes - Major \\
\hline Dublin North West & $20,792(-11.9 \%)$ & 3 & No & $22,834(-3.2 \%)$ & Yes - Major \\
\hline Dublin South & $23,455(-0.6 \%)$ & 5 & No & $23,056(-2.3 \%)$ & Yes - Minor \\
\hline Dublin South Central & $23,604(+0.0 \%)$ & 5 & No & $23,795(+0.8 \%)$ & Yes - Minor \\
\hline Dublin South East & $24,274(+2.9 \%)$ & 4 & No & $24,274(+2.9 \%)$ & No \\
\hline Dublin South West & $23,355(-1.0 \%)$ & 4 & No & $23,853(+1.1 \%)$ & Yes - Minor \\
\hline Dublin West & $27,475(+16.4 \%)$ & 3 & No & $24,395(+3.4 \%)$ & Yes - Major \\
\hline Dun Laoghaire & $23,257(-1.4 \%)$ & 5 & No & $23,257(-1.4 \%)$ & No \\
\hline Galway East & $22,677(-3.9 \%)$ & 4 & No & $22,677(-3.9 \%)$ & No \\
\hline Galway West & $23,674(+0.3 \%)$ & 5 & No & $23,674(+0.3 \%)$ & No \\
\hline Kerry North & $21,719(-8.0 \%)$ & 3 & No & $22,131(-6.2 \%)$ & Yes - Minor \\
\hline Kerry South & $22,456(-4.8 \%)$ & 3 & No & $22,045(-6.6 \%)$ & Yes - Minor \\
\hline Kildare North & $28,491(+20.7 \%)$ & 3 & Yes; $4(+1)$ & $23,757(+0.7 \%)$ & Yes - Minor \\
\hline Kildare South & $26,157(+10.8 \%)$ & 3 & No & $22,972(-2.7 \%)$ & Yes - Major \\
\hline Laois Offaly & $24,487(+3.8 \%)$ & 5 & No & $24,487(+3.8 \%)$ & No \\
\hline Limerick East & $22,930(-2.8 \%)$ & 5 & No & $22,490(-4.7 \%)$ & Yes - Minor \\
\hline Limerick West & $21,522(-8.8 \%)$ & 3 & No & $22,598(-4.3 \%)$ & Yes - Major \\
\hline Longford Roscommon & $21,210(-10.1 \%)$ & 4 & See below & See Below & Yes - Minor \\
\hline Louth & $25,455(+7.9 \%)$ & 4 & No & $25,455(+7.9 \%)$ & No \\
\hline Mayo & $23,489(-0.5 \%)$ & 5 & No & $23,489(-0.5 \%)$ & No \\
\hline Meath & $26,801(+13.6 \%)$ & 5 & See below & See Below & Yes - Major \\
\hline Sligo Leitrim & $21,000(-11.0 \%)$ & 4 & See below & See Below & Yes - Major \\
\hline Tipperary North & $23,476(-0.5 \%)$ & 3 & No & $23,708(+0.5 \%)$ & No \\
\hline Tipperary South & $23,708(+0.5 \%)$ & 3 & No & $25,031(+6.1 \%)$ & No \\
\hline Waterford & $25,031(+6.1 \%)$ & 4 & No & $23,953(+1.5 \%)$ & No \\
\hline Westmeath & $23,953(+1.5 \%)$ & 3 & See below & See Below & Yes - Major \\
\hline Wexford & $23,319(-1.2 \%)$ & 5 & No & $23,319(-1.2 \%)$ & No \\
\hline Wicklow & $23,662(+0.3 \%)$ & 5 & No & $23,662(+0.3 \%)$ & No \\
\hline \multicolumn{6}{|l|}{ New Constituencies } \\
\hline Longford Westmeath & & 4 & & $24,113(+2.2 \%)$ & \\
\hline Meath East & & 3 & & $23,414(-0.8 \%)$ & \\
\hline Meath West & & 3 & & $23,412(-0.8 \%)$ & \\
\hline Roscommon-South Leitrim & & 3 & & $23,631(+0.1 \%)$ & \\
\hline Sligo-North Leitrim & & 3 & & $22,294(-5.5 \%)$ & \\
\hline
\end{tabular}

Source: Constituency Commission, 2004. 
On 9 October 2003, the commission produced a report outlining constituency boundaries for the 2004 European elections. The commission drew up these boundaries in the context of the aforementioned population changes, as well as that of European Union enlargement, which resulted in the number of MEPs allocated to the Republic of Ireland being reduced from 15 to13. The commission recommended that the boundaries of Dublin remain unchanged, with Dublin to also retain its four MEPs. The former Leinster constituency was to lose an MEP and to be renamed as the East constituency. Munster lost a seat and was renamed as the South constituency, while Clare was moved into the former Connacht-Ulster constituency, which was renamed as the North West constituency. These recommendations were largely conservative, involving minimal boundary changes, and this resulted in considerable variation in the population-to-MEP ratio between the different constituencies, as shown in Table 2. The average population per MEP in East and South was left below the state average of 301,323, with the ratios in Dublin and North West below this. If present population trends continue, the level of variance in the Dublin and South constituencies will be reduced. However, a further transfer of territory might be necessary to maintain the MEP to population ratio in North West at an acceptable level, probably involving the transfer of Longford from East.

The small number of seats involved limited the scope for dramatic changes to the European Parliament constituencies. However, the report on Dáil constituency boundaries recommended considerable changes, particularly in the Greater Dublin, Cork, North West and North Midlands regions, as illustrated by Table 1 . Just 16 of the 42 existing constituencies were left unaffected by the changes; the commission's report affected 68 per cent of all the existing constituencies. The population per TD ratios in Louth and Waterford are still significantly higher than the state average,

TABLE 2

RECOMMENDED CHANGES TO EUROPEAN PARLIAMENT CONSTITUENCY BOUNDARIES AND SUBSEQUENT CHANGES TO POPULATION TO TD RATIOS

\begin{tabular}{|c|c|c|c|c|c|c|}
\hline \multicolumn{3}{|c|}{ Before boundary change } & \multicolumn{4}{|c|}{ After boundary changes } \\
\hline $\begin{array}{l}\text { Constituency } \\
\text { (1999) }\end{array}$ & $\begin{array}{c}\text { Population per } \\
\text { MEP ( } \pm \text { national } \\
\text { mean in } \%)\end{array}$ & $\begin{array}{l}\text { Seats } \\
(1999)\end{array}$ & $\begin{array}{c}\text { Constituency } \\
(2004)\end{array}$ & $\begin{array}{l}\text { Loss of } \\
\text { seat }\end{array}$ & $\begin{array}{c}\text { Population per } \\
\text { MEP ( } \pm \text { national } \\
\text { mean in } \%)\end{array}$ & $\begin{array}{c}\text { Territorial } \\
\text { changes }\end{array}$ \\
\hline Dublin & $280,705(+7.5 \%)$ & 4 & Dublin & No & $280,705(-6.8 \%)$ & No \\
\hline Leinster & $245,690(-5.9 \%)$ & 4 & East & Yes; $3(-1)$ & $327,586(+8.7 \%)$ & No \\
\hline Munster & $275,153(+5.4 \%)$ & 4 & South & Yes; $3(-1)$ & $332,446(+10.3 \%)$ & Yes \\
\hline Connacht-Ulster & $237,003(-9.3 \%)$ & 3 & North West & No & $271,429(-9.9 \%)$ & Yes \\
\hline
\end{tabular}

Source: Constituency Commission, 2003. 
while those in Cavan-Monaghan, Kerry North, Kerry South and SligoNorth Leitrim are still well below. Should present population trends continue over the next five years, the next report of the commission will be likely to recommend further boundary changes, which could particularly affect these constituencies. The demographic dynamism of areas, such as the inner city and outer suburbs of Dublin, as well as its rapidly expanding commuter belt, might also necessitate further changes.

Boundary changes are of concern to politicians for two reasons. First, a constituency may gain or lose a seat as a result of a boundary amendment. The gain of a seat means that smaller parties have a better chance of winning, or holding, seats, as this will reduce the percentage share of the vote that is required to reach the quota in that constituency. On the other hand, the loss of a seat increases the percentage share of the vote required to reach the quota, and also ensures that at least one sitting TD will lose their seat in that constituency. Smaller political parties, such as Sinn Féin and the Green Party, have criticised the report for reducing their electoral prospects, as the commission has recommended a reduction in the number of five-seat constituencies and an increase in the number of four-seat and three-seat constituencies. New boundary configurations in Meath and the North West have significantly reduced Sinn Féin's prospects of making gains in these areas in the next general election. This is also the case with the Green Party in Dublin North Central. Donnelly (2004), however, has argued that the boundary changes will not involve any significant impact on the electoral prospects of the different political parties. Predicted losses for Fianna Fáil in Cork North Central and SligoNorth Leitrim are likely to be offset by potential gains in Kildare North and Dublin Mid West. Labour's prospects of regaining seats in Dublin North Central, Meath and Sligo-North Leitrim have been significantly reduced, but its prospects in Dublin Mid West have improved significantly. Unexpected changes in party support may further exacerbate, or offset, the impact that seat-losses have on the electoral prospects of parties and candidates. In the 2002 general election a number of Fine Gael losses were associated with constituencies that had lost seats in the 1998 boundary revisions. Dublin North East and Dublin South West lost seats in these revisions, and Fine Gael TDs Michael Joe Cosgrave and Brian Hayes lost these seats in the 2002 election.

A second cause of concern for politicians is focused on how transfers of territory between constituencies may impact on the electoral prospects of politicians in these areas, particularly if the amendment involves their home area, or bailiwick. The 'friends and neighbours' effect argues that an election candidate will generally win their largest share of the vote in the area around their home base and that their share of the vote will decline 
the further they move away from this bailiwick. This effect is particularly important in the highly localised and clientilistic Irish political system, and research by Parker (1982) and Johnston (1985) showed that this effect had a significant effect on voting patterns in Galway West and a number of Dublin constituencies. In line with this effect, the loss of part, or all, of a politician's bailiwick arising from a boundary change will mean that they risk losing a significant share of their first preference vote, which may, in some cases, result in the loss of a seat. Politicians that were adversely affected by the 2004 revisions included Batt O'Keefe, whose Ballincollig base was moved out of Cork South Central, as well as John Ellis and Gerry Reynolds, whose Leitrim base has been divided with the creation of the Sligo-North Leitrim and Roscommon-South Leitrim constituencies. The transfer of the Coole electoral area, in the north-east of Westmeath, into the new Meath West constituency has also had an adverse effect on the electoral prospects of some candidates based in the former Westmeath constituency. Were support patterns to remain at the 2002 levels, Donie Cassidy would lose almost 1,800 , or 27.2 per cent, of his first preference vote. Cassidy won over 53 per cent of the vote in the Coole area in 2002 and his home town of Castlepollard is also located in this area. Paul McGrath would lose over 800 votes, or 18.1 per cent of his first preference vote. Politicians located in the Athlone area in the extreme west of the county, by contrast, would be the least likely to be affected by the boundary change and this may actually restore an elected representative to the area. Athlone-based Mary O'Rourke would lose less than 100 of her first preferences (1.7 per cent) and her support levels would increase relative to those of her Fianna Fáil running mate, Cassidy. Based on the 2002 figures, three sitting TDs, Cassidy, McGrath and Mae Sexton from Longford, risk losing their Dáil seats due to the boundary changes. ${ }^{1}$

Boundary changes also have an impact on areas. This is most evident with the case of Leitrim, which has been divided as a political unit in the commission's recommendations. At present, Leitrim, Cavan and Carlow are the only counties in Ireland to have just one TD and there is a general feeling that Leitrim risks losing the county's one parliamentary representative due to the boundary changes. Given the highly localised and clientilistic nature of Irish politics, a county, or area, that lacks a TD runs the risk of becoming politically marginalised and this may lead to increased levels of political disengagement and lower levels of electoral participation in these areas. Similar levels of political disengagement may be experienced by others areas, which may have been central areas in their old constituencies but now find themselves as peripheral units on the edge of new constituencies. Examples of such areas include the aforementioned Coole area in Westmeath, and the Beaumont-Whitehall area, which was 
moved from Dublin North Central to Dublin North West. In the 2002 general election the Coole area had a turnout rate of 69.1 per cent and there is a strong likelihood that participation levels may fall there in the next general election if no strong Westmeath-based candidate contests Meath West. Boundary changes may also demobilise populations in the affected areas, if they cannot recognise any of the political representatives in their new constituency or if they are left confused as to which constituency they now find themselves located in. There is evidence that constantly changing Dáil boundaries in parts of the South West Inner City of Dublin have acted to demobilise voters in these areas (Kavanagh, 2002).

Concerns relating to the impact of the changing electoral boundaries received considerable coverage in provincial newspapers in the areas concerned in the week following the publication of the Report, although the perspectives of these papers varied considerably. The reaction in the Leitrim Observer was overwhelmingly negative, focusing largely on the adverse impacts of the county being split in two, as was dramatically illustrated by an image on the front cover of Leitrim county being split in two by a thunder bolt. The paper also reported on the launch of a campaign by the Drumshambo Community Development Company to collect 20,000 signatures across the county in protest at these proposals. The Observer particularly focused on the likelihood of the county being left without Dáil representation, and reported Senator Paschal Mooney's view that this amounted to "political murder" (Halligan, 2004: 1), a view which the paper strongly backed in its editorial:

The county has been effectively split into two, a geographical and psychological division which many have been trying to reverse in recent years. The latest move only seeks to reinforce this north and south Leitrim attitude that is still quite prevalent in the county ... One strong message to have come out of the whole debate is that if the Leitrim electorate want to see a fellow county man sitting in the Dail Chamber in 2007 they must vote for the county. Party politics must be put aside to ensure that we return one of our own (Leitrim Observer, 2004: 6).

By contrast, newspapers in neighbouring Longford and Roscommon generally viewed the report as being both long-awaited and welcome. The Longford News welcomed the end of the Longford Roscommon constituency, 'an unnatural alliance, straddling two provinces, two health boards, with the Shannon dividing the constituency', while the new LongfordWestmeath constituency was viewed as a more natural arrangement (Mullins, 2004: 3). The Roscommon Champion agreed that Longford Roscommon had proven to be 'an unconvincing marriage and divorce was an inevitability' and saw a 'fair degree of logic behind the decision to align 
South Leitrim with Roscommon' (Healy, 2004a: 12). The new Roscommon-South Leitrim constituency was also expected to make the previously peripheral North Roscommon area a 'prime battleground at the next election' (Healy, 2004b, 12):

Clearly the new configuration is a boost to North Rsocommon, and one that was needed. At present there is no TD resident in the north of the county after the next election it is almost certain that a TD will be based in the North Roscommon/South Leitrim region (Healy, 2004a: 12).

Newspapers elsewhere, such as Limerick, Cork and Westmeath, largely focused on the impact that the changes would have on the electoral prospects of individual politicians. The Westmeath Examiner argued that the change would mean that Donie Cassidy 'would struggle to win a seat in either the new Longford-Westmeath constituency or Meath West' and that the other Westmeath TDs, Paul McGrath and Wille Penrose, would also be effected (Newman, 2004: 1). Its editorial strongly criticised the breaching of the Westmeath county boundary, however, and argued that 'a dog's dinner had been made of the electoral make-up' by the commission (Westmeath Examiner, 2004: 7). Newspaper coverage of the boundary changes in The Southern Star and the Limerick Leader was not as detailed as that in their North Western and Midland counterparts, while papers in unaffected areas, such as the Leinster Express in Laois, largely ignored the commission report. The Southern Star and the Limerick Leader focused their relatively concise coverage on the electoral impacts of the changes, with The Southern Star arguing that the decision to move Ballincollig from Cork South Central into Cork North West had effectively left local TD, Batt O'Keefe, 'between a rock and an even harder place' (O'Donovan, 2004: 1).

Boundary changes will have an impact on the relative difference in turnouts between constituencies. This is apparent when one contrasts the low turnout constituencies in the 1997 general election with those for the 2002 contest. The three constituencies with the lowest turnouts in 1997 were Dublin South West (55.9 per cent), Dublin Central (56.6 per cent) and Dublin South East (57.7 per cent). By 2002 the lowest turnout constituencies were Dublin South Central (52.0 per cent) and Dublin Mid West (52.0 per cent). Differences between the elections partially resulted from the boundary changes in the 1998 commission report. The higher turnouts in the South West and Central constituencies relative to Mid West and South Central resulted from high turnout areas such as Templeogue and Drumcondra being moved into South West and Central respectively. The relative decline in South Central and Mid West resulted from the commission's decision to move the low turnout Ballyfermot and 
FIGURE 1

VOTER TURNOUT RATES FOR THE 2002 GENERAL ELECTION, AS BASED ON THE NEW BOUNDARY CONFIGURATION SET OUT BY THE 2004 CONSTITUENCY COMMISSION

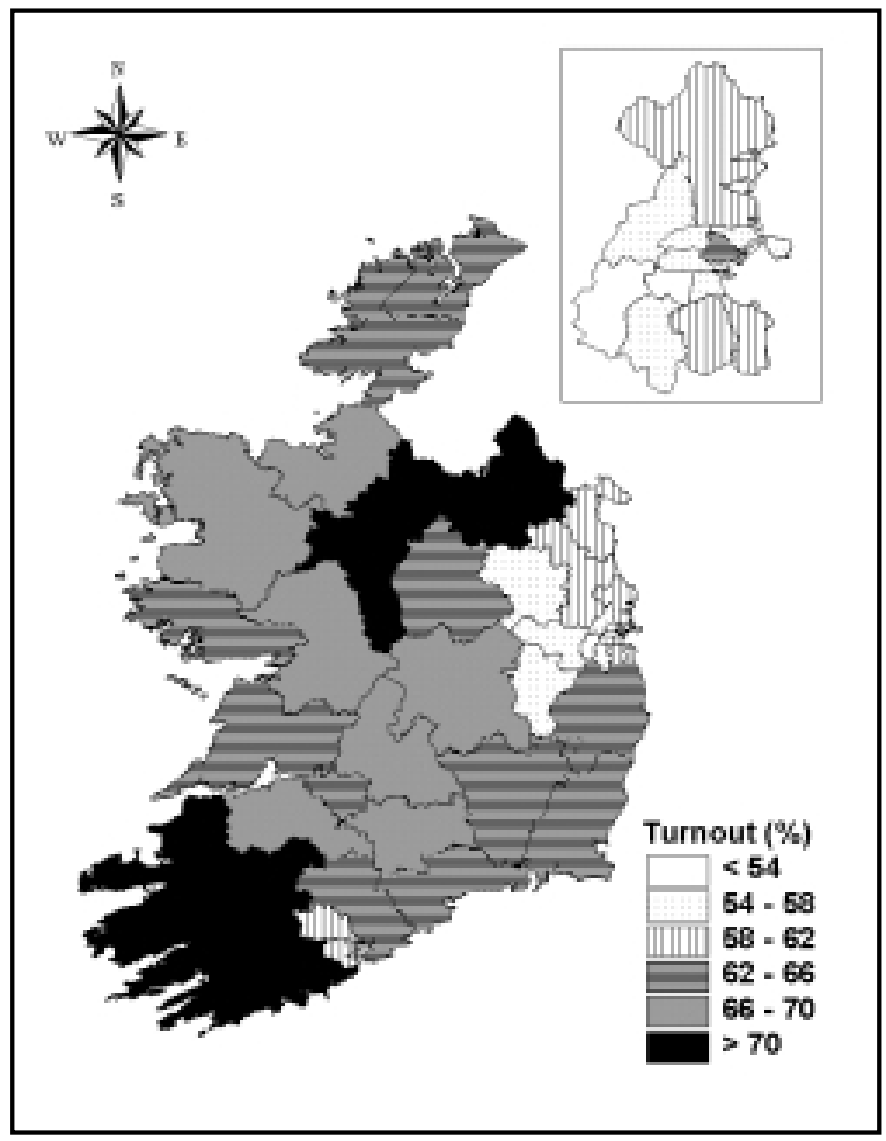

South West Inner City areas into South Central and the low turnout North Clondalkin area into Mid West. The changes recommended by the present Constituency Commission will also impact on constituency-level turnout variations in the next general election. To test this, turnouts for the new, or redrawn, constituencies, based on the figures for the 2002 general election, can be calculated arising from a marked register analysis of those figures, which allows one to attain highly detailed statistics on turnout levels for the areas affected by the boundary changes. This suggests that the constituency changes will not have as dramatic an impact 
as the previous revisions had, with the most significant changes concentrated in the Cork region - turnout would be expected to increase by 1.5 per cent in Cork North Central and to decrease by 1.7 per cent in Cork North West and by 1.3 per cent in Cork South Central. These limited effects may be due to the fact that the boundary changes have not altered the socio-economic compositions of constituencies to the same degree as the 1998 amendments, being mindful of the strong association that exists in Ireland between urban social deprivation and lower turnout (Kavanagh, 2002). The sum effect of these boundary changes on constituency level turnouts are illustrated by Figure 1, which shows the map of general election turnouts in 2002, as based on the new constituency configuration outlined in the 2004 Constituency Commission report.

To conclude, while the changes made by the commission in relation to European Parliament constituency boundaries were rather conservative, population shifts between the 1996 census and the 2002 census have required the Constituency Commission to make dramatic changes to Dáil constituency boundaries. These changes will have an especially serious impact for individual politicians, if part of their bailiwick is moved into adjacent constituencies or if the number of seats in their constituency is reduced. The changes may impact on political parties' electoral prospects, and small political parties may find it more difficult to win seats as the number of smaller, three-seat, constituencies has increased. However, the political climate at the next general election will have a much greater bearing on party fortunes than the boundary changes will have. The high degree of localism in Irish politics ensures that the boundary changes will impact particularly on places. It is quite clear that some areas may lose out as a result of changes that cause them to lose their local representatives and to become peripheral units in their new constituencies. The consequent risk is that this will lead to increased levels of political alienation and lower voter turnout levels in these areas.

\section{Acknowledgements}

Marked register turnout figures for the 2002 General Election, as referred to in this article, were calculated as part of a research project involving the Institute for the Study of Social Change (ISSC), UCD, and the National Institute for Regional and Spatial Analysis (NIRSA), NUI Maynooth. The author is particularly grateful to the ISSC/NIRSA student interns, Catherine Duffy and Cormac Walsh, for their involvement in this project

\section{Notes}

1. The tally figures used in this paper were published for the Westmeath constituency in the Westmeath Examiner, 23 May 2002. 


\section{References}

Constituency Commission. 2003. Constituency Commission Report on European Parliament Constituencies, 2003. Dublin: The Stationery Office.

Constituency Commission. 2004. Constituency Commission Report on Dáil Constituencies, 2004. Dublin: The Stationery Office.

Donnelly, Sean. 2004. 'Constituency Changes Can Be Hard on Individuals, but Parties Can Relax', The Irish Times, 9January.

Halligan, Neil. 2004. 'Constituency Split Provokes Anger in County', Leitrim Observer, 14January.

Healy, Sean. 2004a. 'Political Divorce Proceedings Begin ... an Old Flame is Back!', Roscommon Champion, 13January.

Healy, Sean. 2004b. 'North Roscommon Could Be Key Battleground in New Roscommon/ South Leitrim Constituency', Roscommon Champion, 13January.

Johnson, Nuala. 1985. Some Aspects of the 1981 General Election in Dublin: A Geographical Analysis, unpublished MA thesis, University College Dublin.

Kavanagh, Adrian P. 2002. Unequal Participation, Unequal Influence. Dublin: South West Inner City Network.

Mullins, Mary. 2004. 'Natural Alliances to be Reunited', Longford News, 14January.

Newman, Sharon. 2004. 'Battle Royal for Seats in Constituency Carve-up', Westmeath Examiner, 17January.

O’Donovan, Frank. 2004. 'Batt “Between a Rock and an Even Harder Place”!', The Southern Star, 17January.

Parker, A.J. 1982. 'The "Friends and Neighbours' Effect in the Galway West Constituency', Political Geography Quarterly, 1:3, pp.243-62.

Westmeath Examiner. 2004. 'Respect', Westmeath Examiner, 17January.

ADRIAN KAVANAGH is a lecturer and researcher in the Department of Geography/ National Institute for Regional and Spatial Analysis, NUI Maynooth. He did his doctoral work on the associations between social deprivation and low voter turnout in the Republic of Ireland and the manner in which these associations may be influenced by geographical context. In Summer 2001 he was lead researcher on a project that studied low voter turnout in the South West Inner of Dublin, which was subsequently published as Unequal Participation, Unequal Influence in 2002. In Summer 2003 he worked on a project to calculate voter turnout rates for the 2002 General Election at an electoral division level for the entire country based on an analysis of the marked registers for that election, a project done in conjunction with the Institute for the Study of Social Change, UCD. 